\title{
Analysis of Statistical Methods for Estimating Solar Radiation
}

\author{
Janković AleksandarA*, Lalić Branislava ${ }^{\mathrm{B}}$ \\ Received: February 18, 2014 | Revised: March 11, 2014 | Accepted: April 2, 2014
}

\begin{abstract}
Daily global radiation is not only required for a large number of ecological, physiological and agro-meteorological models but also is required for the design and evaluation of solar energy systems. Global radiation data is quite frequently not available for all locations. For such locations daily global radiation can be estimated statistically using continuous series of other measurable meteorological parameters. This paper considers four statistical methods for estimating the daily global radiation: AngstromPrescott, Coulsen, Hargreaves and Supit-van Kapel method. The empirical coefficients that characterize these methods were determined using the least squares method for the two locations near Belgrade in Serbia. The results showed that calculated empirical coefficients are similar to values that were previously determined in similar researches for neighboring countries. Further analysis verified accuracy and applicability of four empirical relations, where Ángstrom-Prescott and Supit-Van Kappel methods proved to be by far the most reliable in the assessment of daily global radiation.
\end{abstract}

Key words: Solar radiation, meteorology, Angstrom-Prescott method, empirical coefficients, Serbia, Belgrade

\section{Introduction}

For stations where the global radiation is not measured or is partly missing there are several techniques for estimating and modeling global radiation. All these models can be divided into two groups. The first group is based on the astrophysical properties of the Earth, atmospheric physics and geometry of location for which global radiation needs to be estimated (Paulescu, et al., 2013). Such modeling is called prognostic or physical modeling, where it is common to model seperately shortwave and longwave solar radiation. The second group includes those models which are based on statistical data or data obtained from satellite observations. This approach is called statistical modeling, where the most commonly used method is based on empirical relations and requires the development of equations for estimating solar radiation ac- cording to the commonly measured meteorological variables. This type of modeling is known as statistical modeling of global radiation. The most accessible and measured data are used as input data for estimating such as sunshine duration, air temperature, air temperature combined with cloudiness and air temperature combined with total daily rainfall (Trnka, et al., 2005).

Researches on the assessment of daily global radiation in this region were carried out in the previous period, but none of these studies included all four referred methods for the area of Belgrade. The best known are studies that Supit and van Kappel (1998) performed for the neighboring countries of Croatia and Slovenia, Katic et al. (1979) for Vojvodina and Paltineanu and Mihailescu (2002) for neighboring Romania.

\footnotetext{
A Faculty of Architecture and Civil Engineering, University of Banja Luka, Stepe Stepanovića 77, 78000 Banja Luka, Bosnia and Herzegovina; ajankovic@agfbl.org

B Faculty of Agriculture, University of Novi Sad, Trg Dositeja Obradovića 8, 21000 Novi Sad, Serbia; branka@polj.uns.ac.rs

* Corresponding author: Janković Aleksandar, e-mail: ajankovic@agfbl.org
} 


\section{Methods and data}

\section{Methods}

Ángstrom proposed model for assesment of daily global radiation that was later altered and improved by Prescott. According to this method daily global radiation $G_{d}$ is dependent on daily solar radiation that reaches the top of the atmosphere $G_{a}$ and the relative sunshine duration $S_{r}$ :

$$
G_{d}=G_{a}\left(a_{a}+b_{a} S_{r}\right)
$$

where $a_{a}$ and $b_{a}$ are empirical coefficients for a given location (Sabziparvar, et al., 2013). Empirical coefficient $a_{a}$ has physical meaning and represents the ratio of solar radiation that reaches the earth's surface on a completely cloudy day and solar radiation that reaches the top of the atmosphere. The sum of coefficients $a_{a}+b_{a}$ represents same ratio of these two variables but during a completely cloudless days (Tahâş, et al., 2011). The values of these coefficients are dependent on geographical location of station. ÁngstromPrescott method is based on the linear relationship between variables.

Atmospheric phenomena that most affect the radiation that reaches the Earth's surface are clouds. On the basis of previous studies Supit and Van Kappel (1998) a method in which dependence is presented in the form of:

$$
G_{d}=G_{a} a_{s} \sqrt{\left(T_{\max }-T_{\min }\right)}+b_{s} \sqrt{1-\frac{n}{8}}+c_{s}
$$

where $n$ represents daily cloudiness in eights, $T_{\max }$ and $T_{\min }$ the maximum and minimum daily temperatures and $a_{s}, b_{s}$, and $c_{s}$ the empirical coefficients (Supit, van Kappel, 1998).

Coulson method gives the empirical relationship between the daily global radiation $G_{d}$ and daily cloudiness $n$ via:

$$
G_{d}=G_{d 0}[1+(1-\xi) n]
$$

where introduced labels have the following meanings, $G_{d o}$ represents daily global radiation that reaches the earth's surface on cloudless day, while $\xi$ represents constant determined by empirical means (Mihailović, 1988).

Hargreaves et al.(1985) proposed simple method for estimating daily global radiation based on daily amplitude of air temperature:

$$
G_{d}=G_{a} a_{H} \sqrt{\left(T_{\max }-T_{\min }\right)}+b_{h}
$$

where $a_{h}$ and $b_{h}$ represent empirical constants (Hargreaves, et al., 1985).

\section{Description of location and data sets}

Ángstrom- Prescott, Supit-Van Kappel, Coulson and Hargreaves methods have been tested for two locations near Belgrade, Zeleno Brdo $\left(44^{\circ} 47 \mathrm{~N}\right.$ and $20^{\circ} 52$ E, $242 \mathrm{~m}$ ) and Pančevo ( $44^{\circ} 50^{\prime} \mathrm{N}$ and $20^{\circ} 40^{\prime} \mathrm{E}, 76 \mathrm{~m}$ ). Data sets of measured global radiation and sunshine duration were required for testing Ángstrom-Prescott method. For verification of Supit-Van Kappel method data sets of measured global radiation, maximum and minimum daily temperatures and cloud cover were required. In Coulson equation daily global radiation that reaches the earth's surface on cloudless day had been determined by statistical analysis as product of the mean annual value of transmitance on cloudless day and daily solar radiation that reaches the top of the atmosphere. In addition to measured global radiation data sets of cloudiness were required for this method. Data sets of measured global radiation and daily temperature amplitude were required for analysis of Hargraves method. Ground measured global radiation had been taken from two meteorological stations at Zeleno Brdo and Pančevo, while data sets of daily cloudiness, sunshine duration, maximum and minimum daily temperatures have been taken from climatological yearbook of RHMS (Republic Hydrometeorological Service of Serbia) (http://hidmet.gov. rs/).

\section{Calculation of empirical coefficients}

Empirical coeficients for Ángstrom- Prescott, SupitVan Kappel, Coulson and Hargreaves equations were calculated using the least squares method. In general case expressions for the coefficients of linear function are obtained by applying the least squares method in the form of:

$$
\begin{gathered}
b=\frac{\sum x \sum y-n \sum x y}{\left(\sum x\right)^{2}-n \sum x^{2}} \\
a=\frac{\sum x \sum x y-\sum x^{2} \sum y}{\left(\sum x\right)^{2}-n \sum x^{2}} .
\end{gathered}
$$

where $x$ and $y$ represent the calculated and measured daily global radiation, while $n$ represents the number of measurements (days) (Irwan, et al., 2012).

Root mean square error $(R M S E)$ in $\left(\mathrm{kJ} / \mathrm{cm}^{2}\right)$ had been calculated in order to verify obtained results as well as the relative error in $\sigma_{G d}(\%)$ :

$$
R M S E=\sqrt{\frac{\sum\left(G_{d}-G_{i}\right)^{2}}{n}}
$$




$$
\sigma_{G_{d}}=\frac{\sum \frac{G_{d}-G_{i}}{G_{o}}}{n}
$$

where $G_{d}$ and $G_{i}$ represent the observed and estimated daily global radiation and $n$ represents number of days for which daily global radiation was estimated and measured (Sabziparvar, 2007).

\section{Results}

Monthly values of empirical coefficients for both stations are shown in Table 1. As previously stated these coefficients are most dependent on the geographic location of station (Rahman, et. al 2005). To validate obtained results we compared values of calculated coefficients for three methods to values that Supit determined in his research for neighboring countries. Average values of calculated empirical coefficients for Ángstrom- Prescott method are approximate to the values that Supit obtained in his research for adjacent land Croatia (Zagreb, $a_{a}=0.22$ and $\left.b_{a}={ }_{0.56}\right)($ Supit, van Kappel, 1998). A similar thing applies to the calculated values of empirical coefficients for Supit-Van Kappel method. They are approximate to values of empirical coefficients that Supit determined on the basis of long-time series of measured global radiation for adjacent land Croatia (Split, $a_{s}=0.11, b_{s}=0.36$ and Zagreb, $a_{s}=0.10, b_{s}=0.32$ ) (Supit, van Kappel, 1998). It must be emphasized that calculated values of empirical coefficients for Coulson method fit almost perfectly with value that Katic and associates determined in their research for Novi Sad in 1978 (Novi Sad, $\xi=1.89$ ) (Mihailović, 1988). As with the first two mentioned methods average values of calculated empirical coefficients correspond to values that Supit determined for neighboring country Slovenia (Ljubljana, $a_{h}=0.18$ and Portorož, $b_{h}=0.22$ ) (Supit, van Kappel, 1998).

Ability of considered methods to truly reproduce daily global radiation in area around Belgrade and the validity of obtained results can be seen in Figure 1 where is shown correlation between the calculated and observed daily global radiation.

Table 1. Calculated empirical coefficients for Ángstrom- Prescott, Supit-Van Kappel, Coulson and Hargreaves methods

\begin{tabular}{|c|c|c|c|c|c|c|c|c|c|}
\hline \multirow{2}{*}{ Station } & \multirow{2}{*}{ Month } & \multicolumn{2}{|c|}{ Ángstrom-Prescott } & \multicolumn{3}{|c|}{ Supit-Van Kappel } & \multirow{2}{*}{$\begin{array}{c}\text { Coulson } \\
\xi \xi\end{array}$} & \multicolumn{2}{|c|}{ Hargreaves } \\
\hline & & $a_{a}$ & $b_{a}$ & $a_{s}$ & $b_{s}$ & $c_{s}$ & & $a_{h}$ & $b_{h}$ \\
\hline \multirow{13}{*}{ Pančevo } & January & 0.17 & 0.50 & 0.07 & 0.35 & 0.00 & 1.83 & 0.17 & -0.26 \\
\hline & February & 0.28 & 0.37 & 0.13 & 0.15 & 0.00 & 1.79 & 0.17 & -0.18 \\
\hline & March & 0.21 & 0.53 & 0.09 & 0.38 & 0.01 & 1.66 & 0.21 & -1.15 \\
\hline & April & 0.18 & 0.57 & 0.08 & 0.39 & -0.07 & 1.88 & 0.25 & -3.03 \\
\hline & May & 0.17 & 0.63 & 0.09 & 0.41 & 0.01 & 1.78 & 0.16 & 0.69 \\
\hline & June & 0.15 & 0.64 & 0.08 & 0.43 & -0.01 & 1.99 & 0.33 & -5.85 \\
\hline & July & 0.16 & 0.64 & 0.06 & 0.53 & 0.00 & 2.01 & 0.27 & -3.27 \\
\hline & August & 0.17 & 0.57 & 0.07 & 0.43 & -0.01 & 2.25 & 0.22 & -1.65 \\
\hline & September & 0.12 & 0.57 & 0.07 & 0.35 & -0.04 & 2.13 & 0.21 & -1.75 \\
\hline & October & 0.16 & 0.42 & 0.07 & 0.28 & -0.04 & 1.87 & 0.19 & -1.15 \\
\hline & November & 0.16 & 0.46 & 0.07 & 0.27 & 0.02 & 1.76 & 0.12 & 0.18 \\
\hline & December & 0.14 & 0.46 & 0.07 & 0.33 & 0.01 & 1.81 & 0.16 & -0.24 \\
\hline & Average & 0.17 & 0.54 & 0.08 & 0.38 & -0.08 & 1.88 & 0.19 & -0.62 \\
\hline \multirow{13}{*}{ Zeleno Brdo } & January & 0.20 & 0.50 & 0.08 & 0.35 & 0.01 & 1.78 & 0.19 & -0.35 \\
\hline & February & 0.21 & 0.55 & 0.07 & 0.45 & -0.01 & 1.60 & 0.20 & -0.56 \\
\hline & March & 0.20 & 0.55 & 0.08 & 0.40 & -0.01 & 1.53 & 0.21 & -1.09 \\
\hline & April & 0.21 & 0.52 & 0.09 & 0.36 & -0.06 & 1.56 & 0.25 & -2.69 \\
\hline & May & 0.19 & 0.59 & 0.08 & 0.41 & -0.04 & 1.31 & 0.27 & -3.96 \\
\hline & June & 0.19 & 0.57 & 0.07 & 0.46 & -0.02 & 1.38 & 0.29 & -4.63 \\
\hline & July & 0.20 & 0.56 & 0.05 & 0.52 & -0.01 & 1.42 & 0.22 & -2.03 \\
\hline & August & 0.20 & 0.56 & 0.09 & 0.34 & -0.02 & 1.53 & 0.22 & -2.04 \\
\hline & September & 0.18 & 0.57 & 0.07 & 0.44 & -0.06 & 1.73 & 0.28 & -3.03 \\
\hline & October & 0.17 & 0.58 & 0.06 & 0.43 & -0.04 & 1.84 & 0.22 & -1.23 \\
\hline & November & 0.20 & 0.48 & 0.07 & 0.36 & 0.00 & 1.80 & 0.18 & -0.32 \\
\hline & December & 0.16 & 0.52 & 0.06 & 0.37 & 0.00 & 1.80 & 0.20 & -0.45 \\
\hline & Average & 0.19 & 0.56 & 0.07 & 0.42 & -0.05 & 1.61 & 0.18 & -0.53 \\
\hline
\end{tabular}



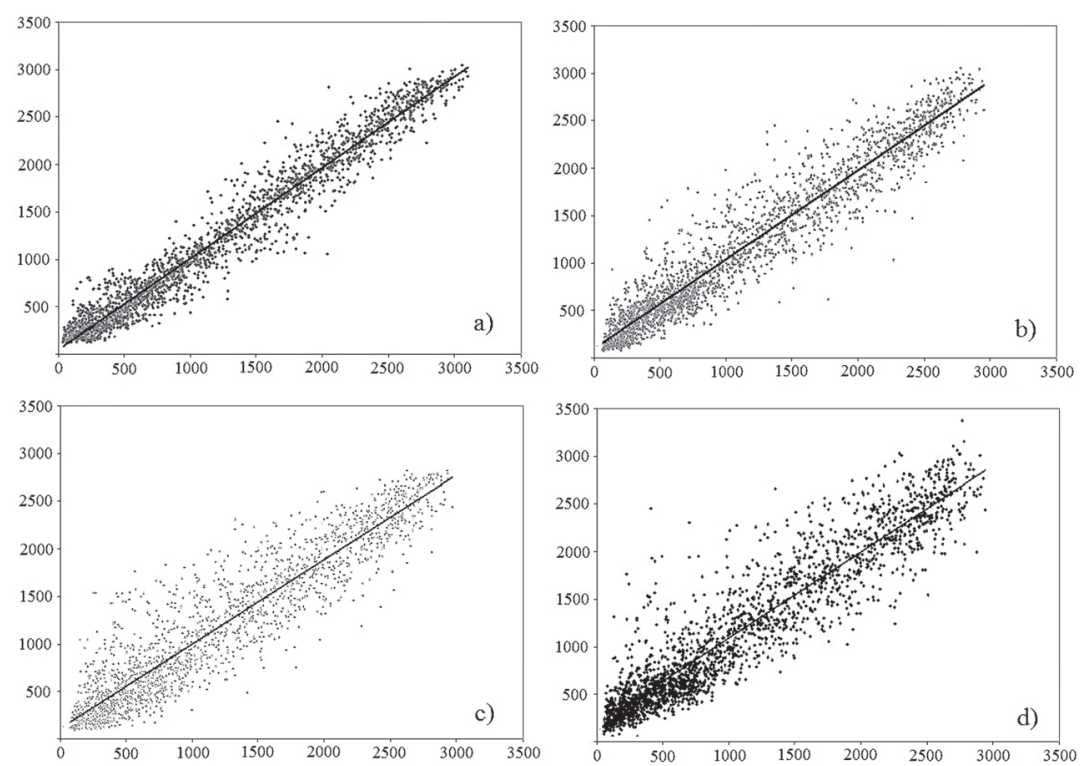

Figure 1. Correlation between observed and measured daily global radiation for a) Ángstrom- Prescott, b) Supit-Van Kappel, c) Coulson and d) Hargreaves methods

Table 2. Root mean square errors (RMSE) and relative errors ( $\sigma$ )

\begin{tabular}{|c|c|c|c|c|c|c|c|c|c|}
\hline \multirow[b]{2}{*}{ Station } & \multirow[b]{2}{*}{ Month } & \multicolumn{2}{|c|}{ Ángstrom-Prescott } & \multicolumn{2}{|c|}{ Supit-Van Kappel } & \multicolumn{2}{|c|}{ Coulson } & \multicolumn{2}{|c|}{ Hargreaves } \\
\hline & & $\begin{array}{c}R M S E \\
\left(\mathrm{~kJ} / \mathrm{cm}^{2}\right)\end{array}$ & $\begin{array}{c}\sigma \\
(\%)\end{array}$ & $\begin{array}{c}R M S E \\
\left(\mathrm{~kJ} / \mathrm{cm}^{2}\right)\end{array}$ & $\begin{array}{c}\sigma \\
(\%)\end{array}$ & $\begin{array}{c}R M S E \\
\left(\mathrm{~kJ} / \mathrm{cm}^{2}\right)\end{array}$ & $\begin{array}{c}\sigma \\
(\%)\end{array}$ & $\begin{array}{c}R M S E \\
\left(\mathrm{~kJ} / \mathrm{cm}^{2}\right)\end{array}$ & $\begin{array}{c}\sigma \\
(\%)\end{array}$ \\
\hline \multirow{13}{*}{ Pančevo } & January & 106.07 & 27.85 & 149.85 & 40.22 & 152.21 & 38.35 & 204.63 & 54.70 \\
\hline & February & 244.91 & 34.64 & 250.13 & 32.67 & 262.59 & 36.96 & 259.05 & 35.69 \\
\hline & March & 334.01 & 33.86 & 416.38 & 46.53 & 418.11 & 53.75 & 469.80 & 57.30 \\
\hline & April & 235.98 & 21.84 & 328.89 & 25.64 & 415.92 & 40.74 & 364.29 & 28.51 \\
\hline & May & 178.67 & 6.33 & 293.55 & 10.85 & 333.50 & 13.52 & 373.31 & 14.27 \\
\hline & June & 201.29 & 8.20 & 259.38 & 10.09 & 360.62 & 15.78 & 344.16 & 14.47 \\
\hline & July & 200.74 & 9.60 & 271.80 & 12.48 & 448.82 & 32.00 & 467.73 & 28.36 \\
\hline & Avgust & 228.58 & 11.14 & 309.82 & 16.84 & 327.09 & 17.38 & 364.94 & 19.57 \\
\hline & September & 273.17 & 26.61 & 337.64 & 31.31 & 391.94 & 39.69 & 374.41 & 34.64 \\
\hline & October & 245.91 & 35.31 & 257.51 & 35.47 & 319.71 & 36.13 & 269.30 & 39.81 \\
\hline & November & 172.27 & 35.84 & 208.80 & 52.44 & 236.02 & 48.06 & 229.55 & 61.63 \\
\hline & December & 99.82 & 44.21 & 122.35 & 48.41 & 122.10 & 49.82 & 149.81 & 62.12 \\
\hline & Average & 253.63 & 30.40 & 297.78 & 36.29 & 343.12 & 52.93 & 354.39 & 44.64 \\
\hline \multirow{13}{*}{ Zeleno Brdo } & January & 91.68 & 32.69 & 115.99 & 33.75 & 128.74 & 38.56 & 164.13 & 53.91 \\
\hline & February & 146.35 & 31.04 & 186.30 & 34.61 & 205.41 & 43.72 & 285.99 & 53.88 \\
\hline & March & 166.81 & 22.75 & 230.38 & 29.52 & 273.28 & 40.23 & 332.71 & 41.53 \\
\hline & April & 252.50 & 24.57 & 275.92 & 24.29 & 388.00 & 43.16 & 313.51 & 26.37 \\
\hline & May & 208.07 & 12.03 & 317.92 & 18.55 & 451.51 & 31.53 & 382.72 & 21.96 \\
\hline & June & 212.13 & 12.06 & 289.96 & 14.04 & 409.83 & 28.02 & 410.85 & 23.33 \\
\hline & July & 191.25 & 11.24 & 323.70 & 15.38 & 382.91 & 24.72 & 516.70 & 30.06 \\
\hline & Avgust & 193.79 & 10.52 & 382.83 & 23.01 & 420.32 & 26.69 & 422.77 & 26.13 \\
\hline & September & 211.32 & 26.68 & 241.98 & 29.37 & 341.44 & 54.20 & 275.74 & 32.83 \\
\hline & October & 123.31 & 24.68 & 195.35 & 32.28 & 234.15 & 47.32 & 251.86 & 40.88 \\
\hline & November & 110.94 & 33.77 & 128.51 & 31.55 & 153.55 & 43.04 & 182.29 & 53.14 \\
\hline & December & 87.31 & 53.05 & 97.51 & 39.54 & 109.36 & 49.81 & 141.88 & 61.20 \\
\hline & Average & 180.00 & 26.29 & 252.07 & 27.70 & 321.60 & 50.79 & 345.43 & 42.01 \\
\hline
\end{tabular}


It was necessary to determine relative $(\sigma)$ and root mean square error (RMSE) for each month in order to quantitatively analyze obtained results. The results are shown in Table 2. All four methods estimate global radiation poorer during the cold period of the year. This applies especially to the months of November and December. On the other hand all four methods estimate daily global radiation very well in the months of June and July.

\section{Conclusion}

Analysis of statistical modeling of global solar radiation included the verification of the accuracy and applicability of four empirical relations: ÅngstromPrescott, Supit-Van Kappel, Coulson and Hargreaves methods for estimating the daily global radiation. It was necessary to determine the coefficients that characterize this geographic area for each of the empirical relations. To determine the coefficients it was necessary to provide a continuous series of measured global radiation as well as the other measured meteorological variables: sunshine duration, daily cloudiness and daily temperature amplitude.

Ángstrom-Prescott method proved to be by far the most reliable in the assessment of daily global radiation. Supit-Van Kappel method has also achieved very satisfactory estimate of daily global radiation. Coulsen and Hargreaves method were chosen for testing because of the ease and availability of data, but on the other hand those two methods proved to be far less able to estimate daily global radiation. Evaluation of daily gloal radiation of the first two methods in the period from April to August is very good. Evaluations for all other months are to be regarded as satisfactory, except for December and November when the relative error is too large. The last two methods estimate daily global radiation well in warmer part of year, but do not estimate at satisfactory level in winter months. The most likely cause of large deviations of predicted value from measured value is the cloudiness that is most difficult to properly parameterize in these relations.

\section{References}

Hargreaves, G.L., Hargreaves, G.H., Riley, P. 1985. Irrigation water requirement for the Senegal River Basin. Journal of Irrigation and Drainage Engineering ASCE 111, 265-275.

Irwan, Y.M., Mohamed, I., Hussin, A. G., Safwati, I., Gomesh, N., Irwanto, M. 2012. Finding the Best Fit for Solar Radiation by statistical comparison between Linear Regression (LS) and Least Trimmed Squares (LTS) Regression Method. International Journal of Engineering \& Computer Science IJECSIJENS Vol: 12 No: 06, 32-36.

Katic, P., Djukanović, D., Djakovic, P. 1979. Climate of SAP Vojvodina. Faculty of Agriculture. Institute of Field and Vegetable Crops, Novi Sad, 237 pp. (in Serbian)

Mihailovic, D., 1988. Basics of meteorological observations and data processing, Faculty of Agriculture. Institute of Field and Vegetable Crops, Novi Sad, 217 pp (in Serbian)

Paltineanu, C.R., Mihailescu, I.R., Torica, V., Albu, A.N. 2002. Correlation between sunshine duration and global solar radiation in south-eastern Romania. International Agrophysics 16, 139-145.

Paulescu, M., Paulescu, E., Gravila, P., Badescu, V. 2013. Weather Modeling and Forecasting of PV Systems Operation, Green Energy and Technology, Springer-Verlag London, 17-42.

Rahman, M.M., Zakaria, M. 2005. Modified Angstrom coefficients for the sunshine-irradiation correlation. Indian Journal of Radio \& Space Physics, Vol. 34, 33-41.

Sabziparvar A. A. 2007. A simple formula for estimating global solar radiation in central arid deserts of Iran. Renewable Energy No: 33, 1002-1010.

Sabziparvar, A.A., Mousavi, R., Marofi, S., Ebrahimipak, N.A., Heidari M. 2013. An Improved Estimation of the Angstrom-Prescott Radiation Coefficients for the $\mathrm{FAO}_{56}$ Penman-Monteith Evapotranspiration Method. Water Resources Management, Volume 27, Issue 8, 2839-2854.

Supit, I., van Kappel, R.R. 1998. A simple method to estimate global radiation. Solar Energy, 147-16o.

Tahâş, S.V., Ristoiu, D., Cosma, C. 2011. Trends of the global solar radiation and air temperature in ClujNapoca, Romania (1984-2008). Atmosphere and earth physics, vol. 56, Nod 5-6, 784-789.

Trnka, M., Žalud, Z., Eitzinger, J., Dubrovsky, M. 2005. Global solar radiation in Central European lowlands estimated by various empirical formulae. $A g$ riculture and Forest Meteorology 131, 55-74.

http://hidmet.gov.rs/ 